\title{
HYPOTETICKÝ DŮKAZ V DIALOGU MENÓN
}

\section{Samuel Zajíček}

Moderní debata o tom, jak interpretovat pasáž v Platónově dialogu Menón, v níž Sókratés Menónovi vysvětluje, co je „zkoumání pomocí hypotézy“ (Meno, 87a1-87b2), se vede již nejméně dvě stě let. ${ }^{1}$ Ačkoli někteří autoři tvrdí, že problém je již vyřešen, ${ }^{2}$ diskuse stále pokračuje a přibývají další interpretace. ${ }^{3}$ Tato stat' se pokusí srozumitelně představit hlavní výkladové možnosti a zhodnotit je jak z hlediska matematického, tak z hlediska jejich důsledků pro filosofickou interpretaci dialogu. V dodatku také navrhne úpravy překladu Františka Novotného tak, ${ }^{4}$ aby odpovídal jednotlivým referovaným možnostem.

\section{Hypotetický důkaz}

Poté, co Sókratés vyložil učení se jako vzpomínání a pomocí názorné

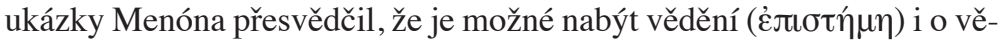
cech, které člověk vůbec nezná (Meno, 81e-86b), vrací se Menón opět k otázce z úvodu celého pojednání, totiž zda má člověk zdatnost (đ̉@etí) od přirozenosti, či nikoli, a pokud nikoli, jak jí lze nabývat, zda učením, cvičením či jinak (Meno, 70a1, resp. 86c7).

Sókratés sice poukazuje na to, že bez znalosti toho, co zdatnost je, lze na tuto otázku odpovědět jen stěží, aby však Menónovi vyhověl, nabízí způsob, jakým by snad bylo možné zjistit, zda ji lze nabývat učením, či nikoli. Pokud by totiž zdatnost byla věděním, byla by naučitelná

1 Nejpozději od roku 1797, viz J. W. Müller, Commentar über zwey dunkle mathematische Stellen in Plato's Schriften, Nürnberg 1797.

2 Např. J. I. Meyers, Plato's Geometric Hypothesis. Meno 86e-87b, in: APEI$R O N, 3,21,1988$, str. 173-180: „Now the picture is complete. The geometrical hypothesis is no longer darkly mysterious or irrelevant. At last it illuminates the way towards a fuller understanding of Meno."

3 Viz naprŕíklad N. Iwata, Plato on Geometrical Hypothesis in the Meno, in: APEIRON, 1, 48, 2015, str. 1-19.

4 Platón, Menón, in: Platónovy spisy, III, přel. F. Novotný, Praha 2003, str. 339-379. 


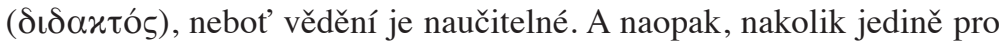
vědění platí, že je naučitelné, natolik platí, že pokud zdatnost věděním není, není naučitelná (Meno, 87b6-87c2).

Sókratés tedy pomocí výše zmíněné ekvivalence převádí otázku po naučitelnosti zdatnosti na zkoumání, zda je zdatnost vědění. Na základě již dříve probíraného tvrzení, že zdatnost je dobro samo ( $\alpha \gamma \alpha \theta$ òv $\alpha$ ư $\tau o ́)$ (Meno, 87d2), ${ }^{5}$ pak zkoumání toho, zda je zdatnost vědění, převádí na otázku, zda může existovat dobro, které by nebylo věděním (Meno, 87d4). Jelikož Menón souhlasí, že dobro je prospěšné ( $\omega \dot{\phi \varepsilon} \lambda \iota \mu \circ \varsigma)$, Sókratés pomocí př́íkladů ukazuje, že prospěšnost u věcí duše - a tedy

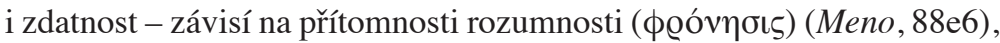
a uzavírá, že rozumnost je tudíž zdatností, bud’ celou, nebo její částí (Meno, 89a3). Menón tedy dovozuje, že zdatnost je vědění, a tedy je možno se jí učit (Meno, $89 \mathrm{c} 1)$.

Zkoumání toho, zda je zdatnost vědění, jež nahrazuje zkoumání toho, zda je zdatnost naučitelná, nazývá Sókratés zkoumáním na základě hy-

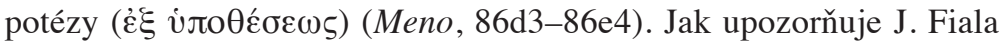
v odkazu na R. S. Blucka, ${ }^{6}$ většina interpretů má za to, že Sókratés tento termín používá technicky, tedy označuje jím nějaký konkrétní postup, a to bud postup analyticko-syntetický, ${ }^{7}$ nebo postup, který Aristotelés, zřetelně odkazující na toto místo v Menónovi, nazývá právě převedením $(\dot{\alpha} \pi \alpha \gamma \omega \gamma \eta \dot{\eta}){ }^{8}$

5 Striktně vzato toto tvrzení nebylo nikdy explicitně odsouhlaseno, Menón se však proti němu neohrazuje, tedy pravděpodobně souhlasí. V tomto ohledu je třeba poznamenat, že někteří interpreti proto vidí v Menónovi hypotézy dvě: první je hypotéza, že zdatnost je vědění, druhou hypotéza, že zdatnost je dobro (viz např. R. S. Bluck, Plato's Meno, Cambridge 1964, str. 81).

6 J. Fiala, $\triangle I O P I \Sigma M O \Sigma$ v Platónově Menónovi $(86 e-87 b)$, in: A. Havlíček (vyd.), Platónův dialog Menón, Praha 2000, str. 7-29. Poznamenejme, že tento článek spolu s textem R. S. Blucka představoval výchozí bod našich úvah o hypotetickém důkazu.

7 Jde o postup, u něhož předpokládáme, že již máme řešení problému, a pouze analyzujeme aspekty tohoto řešení, přičemž na základě této analýzy syntetizujeme konstrukci, která k řešení vede. Například máme-li nad danou úsečkou sestrojit rovnoramenný pravoúhlý trojúhelník tak, aby daná úsečka byla jeho přeponou, pak konstatujeme, že neznámý vrchol trojúhelníku bude ležet jednak na kolmici k úsečce vedené $\mathrm{z}$ jejího středu, jednak na kružnici sestrojené nad touto úsečkou jako svým průměrem. Obě tyto entity již však umíme zkonstruovat, a můžeme tedy syntetizovat řešení spočívající v jejich konstrukci a ve stanovení hledaného vrcholu jako jejich průsečíku.

8 Aristotelés, An.pr. 69a20 n. 
Aby Menónovi vysvětlil, jaký postup má na mysli, dává Sókratés př́íklad:

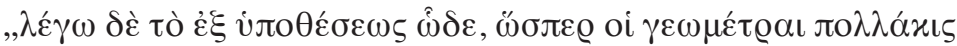

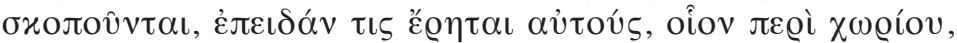

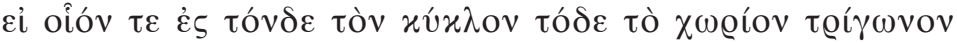

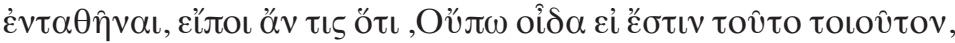

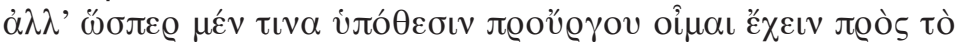

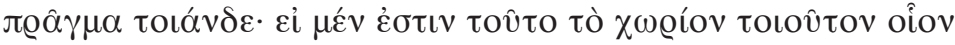

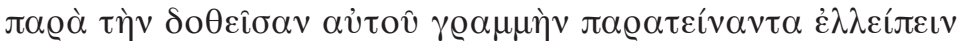

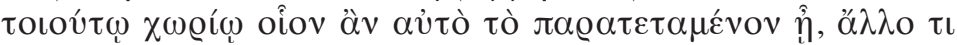

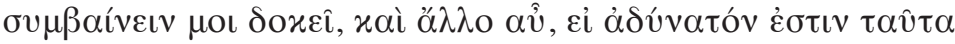

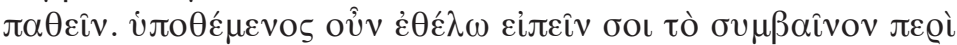

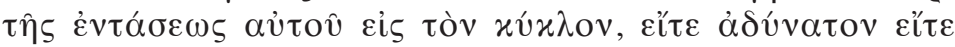
$\mu \eta \dot{. “ * 9}$

„Slovy ,s užitím předpokladu“ rozumím zkoumati tak, jak to často dělají geometrové. Když se jich někdo otáže například o ploše, zdali je možno do tohoto kruhu tuto zde plochu vepsat jako trojúhelník, řekl by některý: Ještě to nevím, zdali je tato plocha taková, ale myslím, že mám jistý vhodný předpoklad pro tuto věc, a to takový: jestliže je tato plocha taková, že když sestrojíme trojúhelník k jeho dané úsečce, je o takovou plochu menší, jako je sám ten přidaný obrazec, zdá se mi, že vychází něco, a zase něco jiného, jestliže není možné, aby se to s ní stalo. S užitím předpokladu tedy ti chci říct, co vychází o jejím vepsání do kruhu, zdali je nemožné, či možné. “"10

Analogie tohoto př́kladu se zkoumáním toho, zda je zdatnost vědění, je jasná a povětšinou na ní panuje shoda. Zadaná plocha (

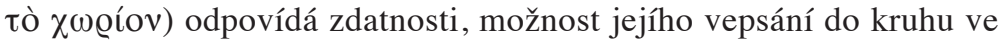

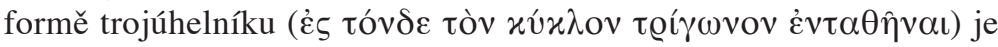
analogická možnosti jejího získání výukou. Ověření kritéria, tedy zda je možné, aby se s plochou stalo to ( $\alpha \hat{v} \tau \alpha \pi \alpha \theta \varepsilon i ̂ v)$, co František Novotný překládá slovy „když sestrojíme trojúhelník k jeho dané úsečce,

9 Platón, Meno, 86e4-87b2, in: Platonis opera, III, vyd. J. Burnet, Oxford 1968.

10 Přejímáme překlad F. Novotného (Platón, Menón, str. 362) s tím, že výraz

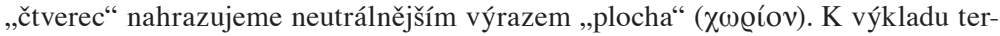
mínu $\chi \omega \varrho i ́ o v$ viz podrobněji níže. 
je o takovou plochu menší, jako je sám ten přidaný obrazec" ( $\pi \alpha \varrho \alpha ̀$

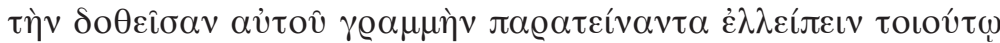

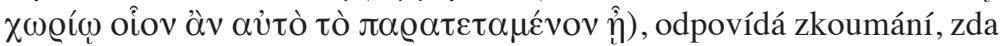
je zdatnost věděním.

\section{Textový ohled}

Ačkoli interpreti jednotně mají za to, že Menónovi musela být daná demonstrace bez obtíží jasná, nebot' metodu bez protestů přijímá, neexistuje shoda na tom, jaké kritérium má Sókratés přesně na mysli, a v důsledku toho ani na tom, jaký přesně je tedy onen postup, který

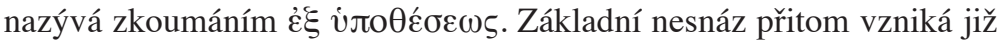

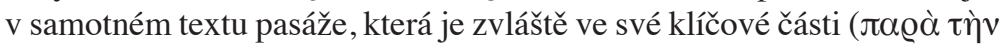

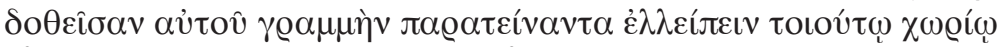

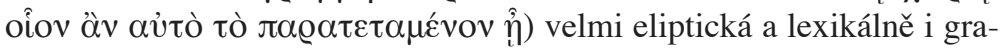
maticky nejasná.

Lexikální obtíže spojené s nejasným významem zjevně technických geometrických termínů se interpreti snaží řešit především komparací s mladším, ale z hlediska geometrie reprezentativním textem Eukleidových Základů. ${ }^{11} \mathrm{~V}$ nich totiž nacházejí text nikoli nepodobný

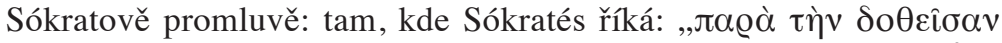

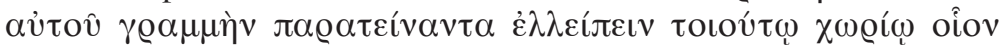

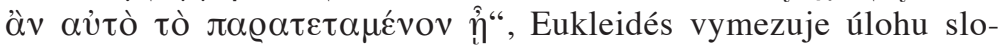

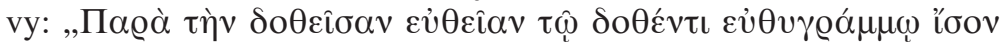

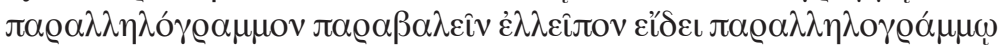

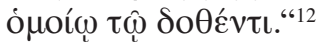

$\mathrm{Z}$ této nepřehlédnutelné podobnosti interpreti usuzují především na

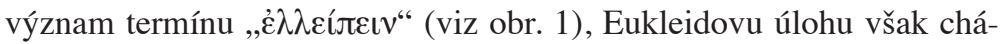

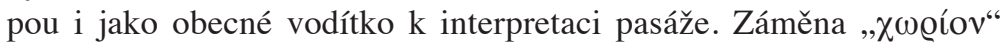

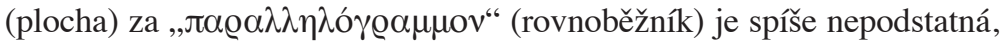

11 Sternfeld a Zyskind s odkazem na Heatha (T. L. Heath, A History of Greek Mathematics, I, Oxford 1921, str. 300) konstatují, že obsah relevantních knih Eukleidových Základů byl v Platónově době již známý, a nejde tedy o anachronismus. R. Sternfeld - H. Zyskind, Plato's Meno: 86E-87A. The Geometrical Illustration of The Argument by Hypothesis, in: Phronesis, 22, 1977, str. 206-211, zde str. 208.

12 Eukleidés, Elem. VI,28. Uvedená formulace v překladu Petra Vopěnky zní: „Přistav k dané úsečce rovnoběžník útvaru danému triangulovatelnému rovný, aby mu scházel doplňovací rovnoběžník danému podobný.“ Eukleidés, Základy. Knihy $V-V I$, vyd. a přel. P. Vopěnka, Nymburk 2009, str. 116. 


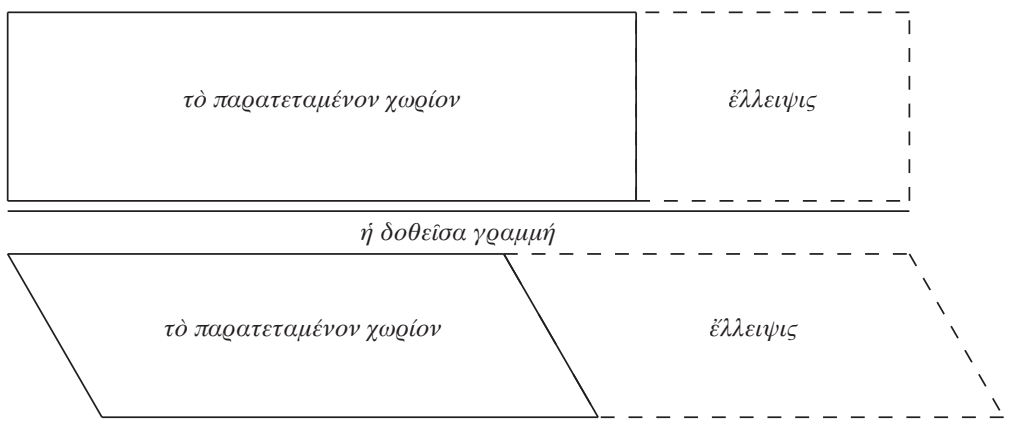

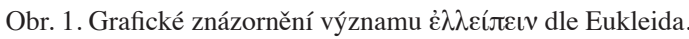

nepodobnost danou užitím „, $\alpha \varrho \alpha \tau \varepsilon i ́ v \omega “$ (protáhnout, natáhnout) namísto

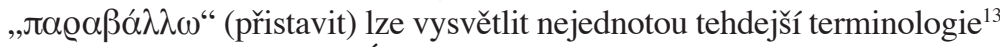
a odkazem na Platónovu Ústavu, kde je řečeno o geometrech, že „, tom smyslu mluví, že plochy přeměňují na čtverce, natahují je podél dané

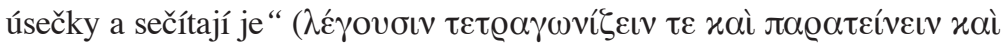

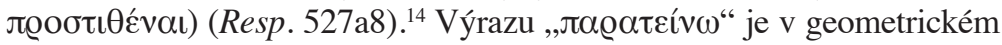
kontextu užíváno zřídka a sám Eukleidés jej nepoužívá, nelze proto vy-

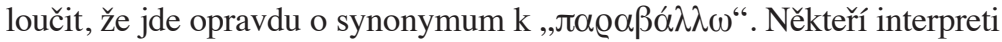
ale naopak právě tento rozdíl považují za důležitý a chápou , $\pi \alpha \varrho \alpha \tau \varepsilon i ́ v \omega$ “ jako „natažení plochy podél úsečky“, tedy jako ekvivalentní transformaci ${ }^{15}$ plochy na obdélník, jehož jednou stranou je právě zadaná úsečka. ${ }^{16}$

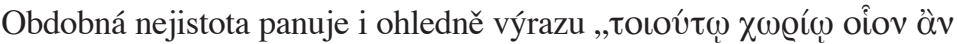

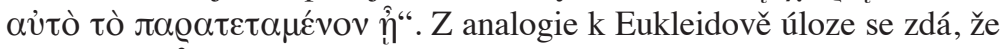

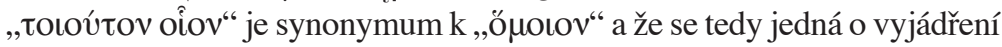
geometrické podobnosti. Ostatně již dříve v dialogu je výraz „,oıoútov

13 „Plato in the Meno and elsewhere uses language partly technical, partly popular... Mathematical phraseology was not nearly so set as in Euclid's time." S. H. Butcher, The Geometrical Problem of the Meno (p. 86e-87a), in: The Journal of Philo$\log y, 17,1888$, str. 221.

14 Český překlad J. Fialy, viz J. Fiala, $\triangle I O P I \Sigma M O \Sigma$ v Platónově Menónovi $(86 e-87 b)$, str. 18. Angličtí autoři překládají $\pi \alpha \varrho \alpha \tau \varepsilon i ́ v \omega$ jako apply, viz např. Grubeho a Reevův překlad: Plato, Republic, přel. G. M. A. Grube - C. D. C. Reeve, in: J. M. Cooper (vyd.), Plato. Complete Works, Indianapolis - Cambridge 1997, str. 1143.

15 Jde tedy o transformaci zachovávající plošný obsah.

16 Srv. např. J. I. Meyers, Plato's Geometric Hypothesis. Meno 86e-87b, str. 176, pozn. 9 . 


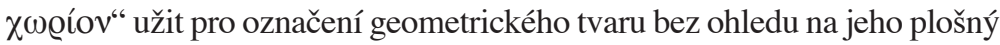
obsah (Meno, 82c4). Někteří interpreti však s touto analogií nesouhlasí a soudí, že jde o vyjádření shodnosti jak tvaru, tak plošného obsahu. ${ }^{17}$

Pasáž je ovšem problematická i po gramatické stránce. První, méně významná obtíž, s kterou je třeba se vyrovnat, spočívá ve spojení

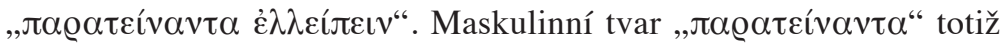
nedovoluje jinak intuitivní mediopasivní čtení, při kterém by podmětem

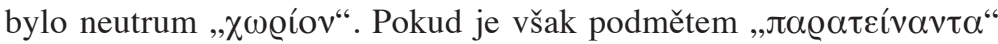
geometr, ${ }^{18}$ měl by být zároveň i podmětem , ,غ่ $\lambda \lambda \varepsilon i ́ \tau \varepsilon \iota v “$, což je ale zejména při technickém čtení tohoto termínu vyloučeno. Butcher proto konstatuje, že jde o nepřekonatelný problém, který je třeba řešit záměnou akuzativu za dativ ${ }^{19}$ Cook Wilson pak odmítá Stallbaumovu konjekturu k participiu aoristu neutra , $\pi \alpha \varrho \alpha \tau \varepsilon i ̂ v \alpha v^{\prime \prime}$ i Butcherovo řešení a navrhuje chápat spojení jako platónský idiom. ${ }^{20}$ Heijboer oproti tomu navrhuje nevykládat ,„غ่ $\lambda \lambda \varepsilon \dot{\tau} \tau \varepsilon \iota v “$ technicky a chápe spojení tak, že je to geometr,

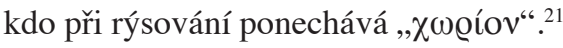

Ve srovnání s touto obtíží, která sice znejasňuje čtení, ale v důsledku nevytváří žádný podstatný interpretační rozdíl, je druhý gramatický

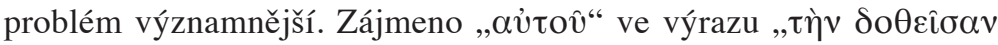
$\alpha$ ưंô̂ $\gamma \varrho \alpha \mu \mu \eta v^{\prime \prime}$ by totiž mělo odkazovat k nejbližšímu podmětu,

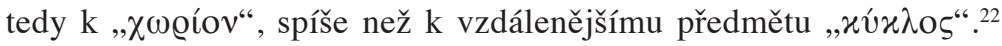

17 Pro podrobnější diskusi viz A. Heijboer, Plato. Meno 86e-87a, in: Mnemosyne, 8,1955 , str. 120 .

18 Jiná maskulina (tj. trojúhelník či kruh) jsou patrně vyloučena, nebot' potom by $\pi \alpha \varrho \alpha \tau \varepsilon i ́ v \alpha v \tau \alpha$ muselo být opět chápáno mediopasivně, bezprostředně následující

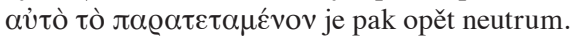

19 „The grammatical difficulty in the accusat. $\pi \alpha \varrho \alpha \tau \varepsilon i v \alpha v \tau \alpha$ is insuperable. If correct, it is a very harsh anacolouthon: ,when you have applied ... it is deficient." The simplest correction would be to the dative." S. H. Butcher, The Geometrical Problem of the Meno (p. 86e-87a), str. 222.

20 „But the text is doubtless sound, and only an instance of a Platonic idiom. Compare Biddell's Digest of Platonic Idioms, 271 b, ,Inversion of Construction.' One

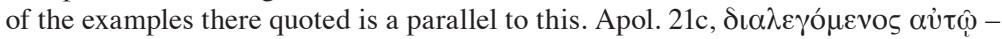

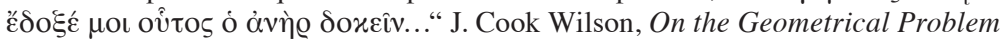
in Plato's Meno, 86e sqq. With a Note on a Passage in the Treatise De Lineis Insecabilibus (970a5), in: The Journal of Philology, 28, 1903, str. 237.

21 „A person engaged in drawing leaves a space, just like the figure he draws.“ A. Heijboer, Plato. Meno 86e-87a, str. 119.

22 Např. J. Cook Wilson, On the Geometrical Problem in Plato's Meno, 86e sqq. str. 236-237, souhlasně se vyjadřuje i Bluck: „Cook Wilson, who is certainly right in

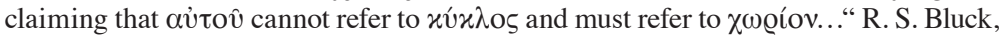


Takové čtení však výrazně znesnadňuje interpretaci, zejména pokud vý-

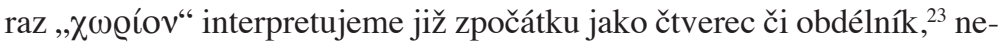

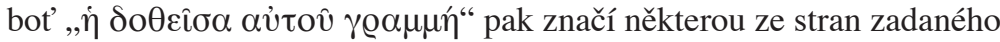
čtverce či obdélníku, a jak upozorňuje Butcher, hrozí, že v textu nezbude žádný potřebný vztah ke kruhu. ${ }^{24}$

\section{Představení jednotlivých řešení}

Textová nejasnost pasáže přirozeně ústí v mnohost interpretací. Existuje více geometrických kritérií či konstrukcí, které určují, že zadanou plochu lze vepsat ve formě trojúhelníku do zadaného kruhu, a jejichž popis více či méně odpovídá Platónovu textu. Překvapivý však může být fakt, že neexistuje shoda ani na základních vlastnostech, které by měla geometrova „hypotéza“" splňovat.

Ačkoli se zdá zjevné, že geometr zakončuje svou promluvu formula-

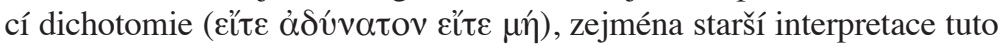
ekvivalenci oslabují na jednostrannou implikaci. Sókratés tak dle nich nechce tvrdit, že „naučitelné je právě a pouze věděni“", ale pouze „vědění je naučitelné" (teoreticky však může být naučitelné i něco jiného). V geometrické analogii hypotetického důkazu toto oslabení znamená: pokud plocha (zdatnost) po př́padné geometrické transformaci splňuje dané kritérium (je věděním), lze ji vepsat do daného kruhu jako trojúhelník se stejným plošným obsahem (je naučitelná). Pokud však nikoli, stále může být možné ji do kruhu vepsat, užitá hypotéza však na rozhodnutí nestačí. ${ }^{25}$

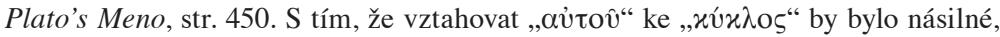
mimo jiné souhlasí i František Novotný, viz Platón, Platónovy spisy, III, str. 512.

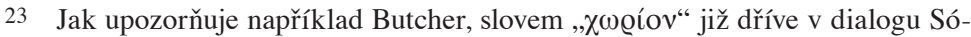
kratés označuje čtverec, viz např. Meno, 82c4, 83a1, 85a4 aj. Ačkoli lze tyto výskyty

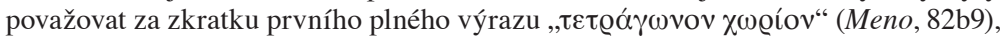

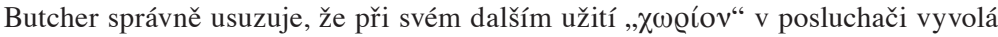
opět dojem čtverce. S. H. Butcher, The Geometrical Problem of the Meno ( $p$. $86 e-$ $-87 a)$, str. 221-222.

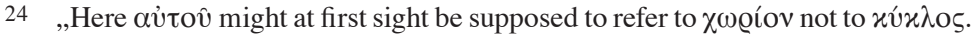
But the sense requires the reference to $x u ́ x \lambda$ os; otherwise there is no mention of the circle in this clause which defines the relations that must exist between the circle

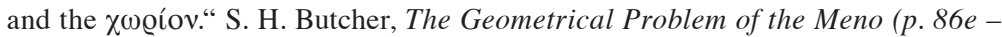
$87 a)$, str. 222. Např́́klad Heijboer však vztah ke kruhu nachází v interpretaci výrazu

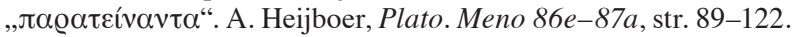

25 Takto je, zdá se, postavena i již zmíněná Aristotelova ỏ $\alpha \gamma \omega \gamma \eta$, viz Aristotelés, An.pr. 69a20 n. 


\section{Interpretace A. Beneckeho}

Takovéto čtení má nepopiratelné výhody, existují totiž velmi jednoduché geometrické konstrukce, kterými může být ukázáno, že danou plochu lze do kruhu vepsat, nikoli však to, že nelze. Jejich elegance spočívá i v tom, že počítají s využitím útvarů, které byly v dialogu narýsovany již dříve. ${ }^{26}$

Právě takovou je dle Bluckova referátu Beneckeho interpretace. ${ }^{27}$ Ten za $\chi \omega \varrho i ́ o v$ pokládá již narýsovaný čtverec a všímá si toho, že pokud je

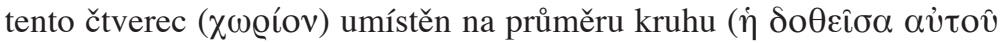

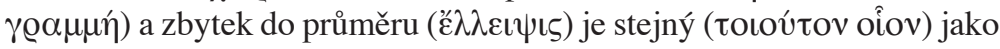
onen čtverec, rovnoramenný pravoúhlý trojúhelník sestrojený nad průměrem bude mít právě žádanou plochu, a bude tedy hledaným vepsáním.

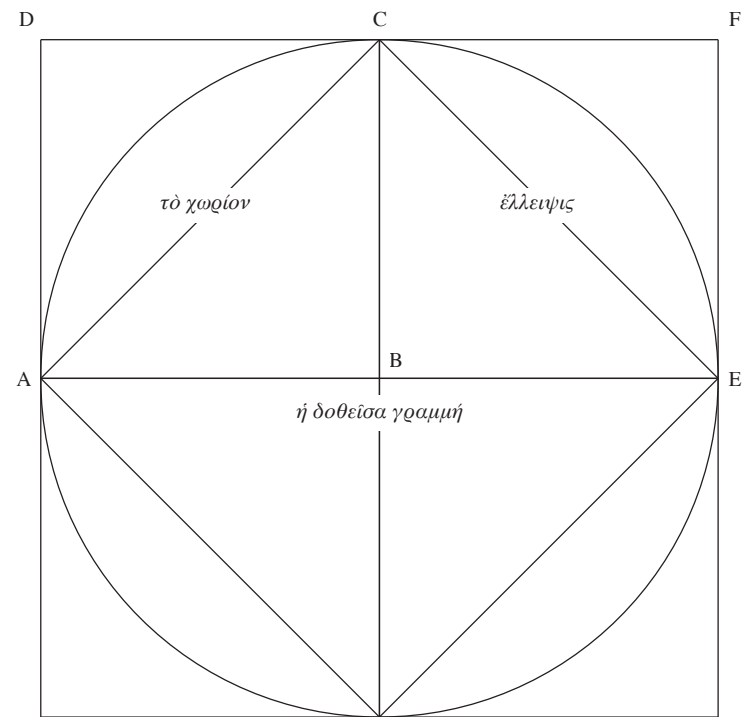

Obr. 2. Beneckeho interpretace. K Sókratem již patrně dříve nakreslenému obrazci je třeba narýsovat jen kruh o průměru $\mathrm{AE}$. Pokud platí, že plocha $\mathrm{ABCD}(\chi \omega \varrho i ́ o v)$ je stejná jako

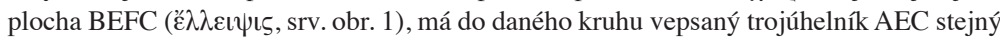
plošný obsah jako čtverec ABCD.

26 Jedná se o čtverec a jeho zdvojení (viz Meno, 82b-85b) a dle Bluckem citovaného Schultze (F. Schultz, Die zweite mathematische Stelle in Platons Menon, in: Neue Jahrbücher für Philologie und Paedagogik, 27, 1882, str. 19-33) možná i kruh (srv. Meno, 74d-74e).

27 R. S. Bluck, Plato's Meno, str. 447; A. Benecke, Über die geometrische Hypothesis in Platons Menon, Elbing 1867. 


\section{Interpretace J. Krále a K. Novotného}

Obdobně jednoduchá je i českému čtenáři známá Králova interpretace, ${ }^{28}$

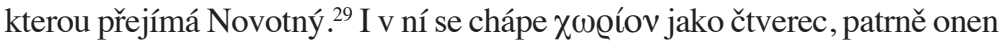
již narýsovaný. Pokud je tento čtverec umístěn do kruhu, který je v písku možná již také přítomen,$^{30}$ tak, aby jeho strana tvořila tětivu, a narýsujeme-li dále pravoúhlý trojúhelník vepsaný do kruhu tak, že jedna jeho strana je přímo onou tětivou a druhá leží na polopřímce dané druhou stranou čtver-

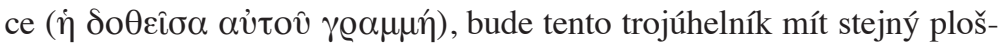
ný obsah jako původní čtverec právě tehdy, když jeho část, která čtverec

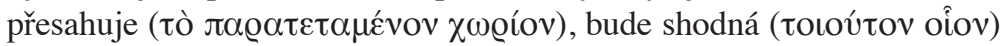
$\mathrm{s}$ částí, kterou trojúhelník ve čtverci ponechal mimo sebe ('̌́ $\lambda \lambda \varepsilon ı \psi \iota \varsigma)$.
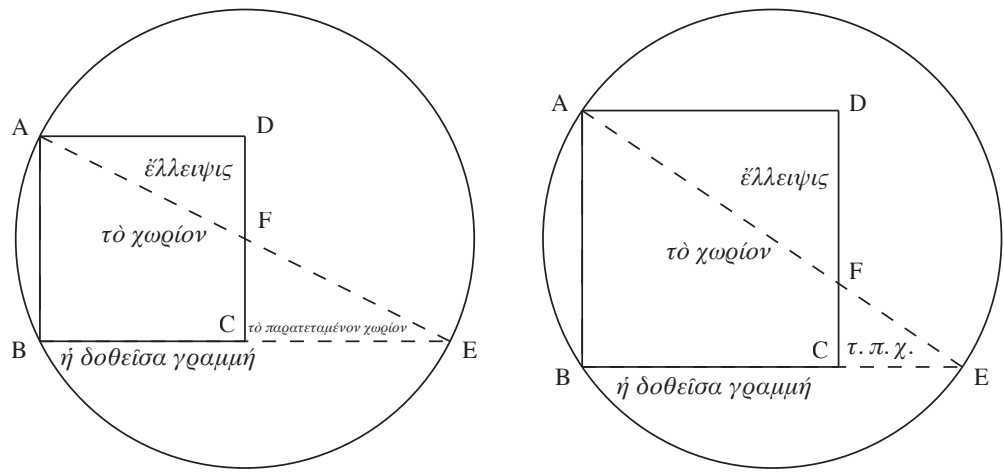

Obr. 3. Novotného interpretace. Xw@íov ABCD vepíšeme do kruhu tak, aby strana AB byla tětivou. Trojúhelník $\mathrm{ABE}$, jehož bod $\mathrm{E}$ je průsečíkem kruhu a polopřímky $\mathrm{BC}$, má

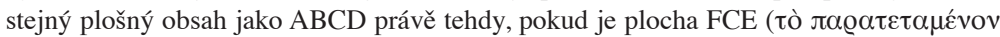

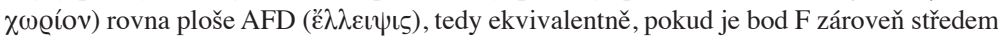
kruhu (nákres vlevo). Pokud bod F není středem kruhu, trojúhelník ABE nemá stejný plošný obsah jako ABCD (nákres vpravo). To nicméně neznamená, že ABCD do kruhu vepsat ve formě trojúhelníku nelze (konkrétně na nákresu vpravo vepsání možné je).

\section{Interpretace S. H. Butchera}

Poněkud jinak postupuje Butcher, ${ }^{31}$ který spolu s Beneckem předpokládá

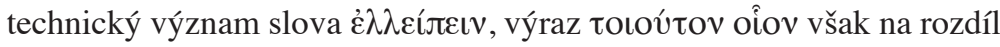

28 J. Král, O geometrické hypothesi v Platónově Menónu, in: Listy filologické, 3, 1876, str. 96-105.

29 Platón, Platónovy spisy, III, str. 512-513, pozn. 25 a 26.

30 Viz pozn. 26.

31 S. H. Butcher, The Geometrical Problem of the Meno (p. 86e-87a), str. 219-225. 


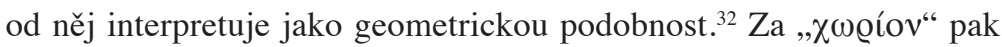
bere libovolný, do písku nově narýsovaný obdélník. Při své interpretaci si všímá toho, že u pravoúhlých trojúhelníků výška spuštěná na přeponu dělí přeponu na dvě části tak, že obdélník daný výškou a jednou částí je podobný obdélníku danému výškou a druhou částí této přepony. ${ }^{33}$ Po-

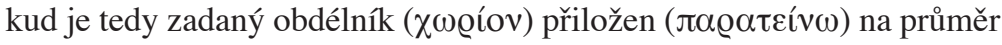
kruhu (†ं

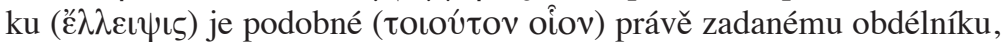
úhlopříčka tohoto obdélníku bude tětivou kruhu, ${ }^{34}$ a tedy rovnoramenný trojúhelník vytknutý úhlopříčkou obdélníku a jeho zdvojnásobenou výškou bude vepsán do kruhu a bude mít stejný plošný obsah jako zadaný obdélník.
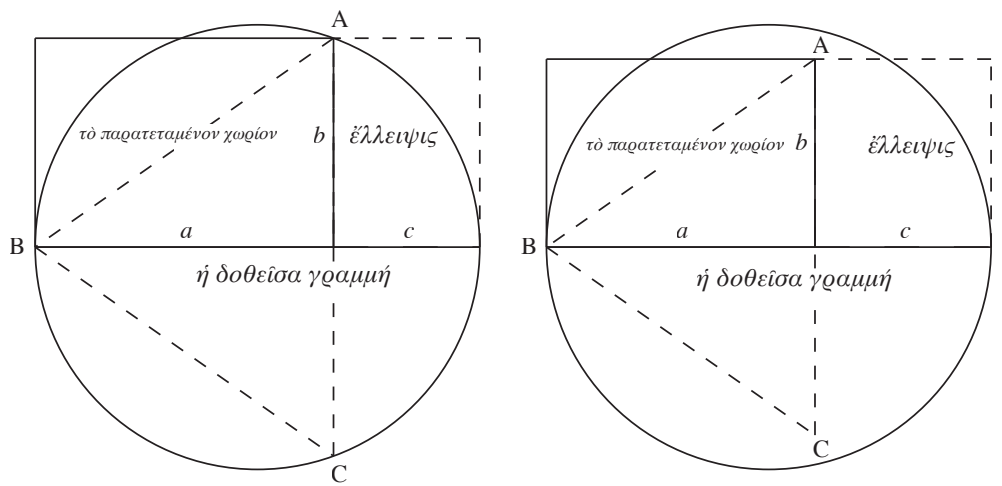

Obr. 4. Butcherova interpretace. Pokud je bod A na kružnici, platí, že a:b = b:c, a tedy $\varepsilon ้ \lambda \lambda \varepsilon \iota \psi \iota \varsigma$ je podobná $\chi \omega \varrho i ́ o v$ a trojúhelník $\mathrm{ABC}$ je hledaným vepsáním (nákres vlevo). Pokud podobná není, bod A na kružnici neleží a trojúhelník vzniklý zrcadlením nebude vepsaný (nákres vpravo).

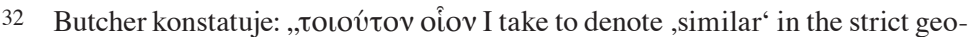
metric sense. Euclid would say ómoíov.“ Tamt., str. 223. Cook Wilson považuje tuto

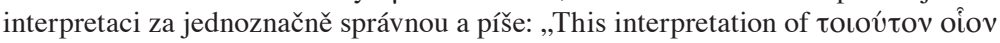
in the geometrical sense of ,similar" is not only the best interpretation of the Greek but agrees with the text of Euclid...", J. Cook Wilson, On the Geometrical Problem in Plato's Meno, 86e sqq., str. 224.

33 Jinými slovy, platí Eukleidova věta o výšce. Tuto větu máme sice poprvé dochovanou právě v Základech (Eukleidés, Elem. VI,8), lze však předpokládat, že v Platónově době již byla známá.

34 Nebot' platí Tháletova věta, v Platónově době již zřejmě také známá. 
Technická jednoduchost a snadná pochopitelnost všech výše uvedených interpretací je však vyvážena jejich problematičností pro filosofické čtení dialogu. Je sice pravda, že Sókratés pro svou další argumentaci nepotřebuje stanovit ekvivalenci vědění a naučitelnosti, trvá pouze na implikaci, že vědění je naučitelné (srv. Meno, 89d3-4), a také v celém dalším běhu dialogu užívá pouze obměnu této implikace..$^{35}$ Přsto však v textu ekvivalenci mezi naučitelností a tím, že je něco věděním či rozumností, několikrát explicitně zmiňuje (Meno, 87c1-3 a 98d10-13), byt' s jistým zlehčením (Meno, 87c8-9).

Avšak i když tato vyjádření dáme stranou, co by taková interpretace znamenala pro celek dialogu? Sókratés by říkal: nevím, zda je zdatnost věcí učení, ale vím, že vědění naučitelné je. Pokud se nám tedy podaří ukázat, že zdatnost je věděním, bude zřejmé, že je naučitelná. Jestliže se nám to však nepodaří, budeme muset postupovat jinak a jinudy.

Tuto strukturu skutečně lze v dalším běhu dialogu vysledovat. V bezprostředně následující pasáži sice Sókratés i Menón shodně konstatují, že zdatnost věděním je (Meno, 87c-89d), vzápětí je však tento závěr zpochybněn $($ Meno, $89 \mathrm{c})$ a pro Menóna dostatečně vyvrácen poukazem na neexistenci učitelů zdatnosti (Meno, 98d-e).

Důkazní postup tedy zřejmě není platný, patrně proto, že pravdivé

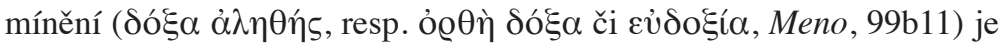
prospěšné, a přitom není věděním (Meno, $97 \mathrm{~b}-\mathrm{c})$, nebot' není svázáno výkladem příčiny (Meno, 97e-98a). Aby totiž bylo možné usoudit, že zdatnost je naučitelná, je zapotřebí ukázat nejen to, že každé dob-

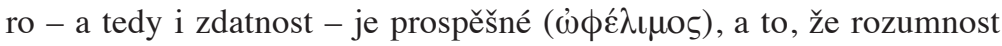

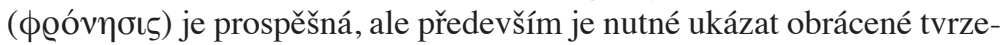
ní, že mimo rozumnost nic prospěšného není.

Máme-li rozhodnout, zda je zdatnost naučitelná, je tedy potřeba užít jiného postupu. Takovýmto postupem je patrně zkoumání, zda existují její učitelé, nebot', jak uznává i Menón, čeho nejsou učitelé ani žáci, to nelze učit (Meno, 89e).

Pokud je tedy hypotetický důkaz interpretován především jako vysvětlení aristotelské $\alpha \pi \alpha \gamma \omega \gamma \eta$, to, že konstrukce stanovují pouze implikaci, odpovídá struktuře dialogu. Pokud by však měl být pochopen jako přesná analogie následujícího zkoumání, měla by patrně existovat možnost, že zdatnost je naučitelná i přesto, že se neukáže být věděním (tj. plochu lze vepsat do kruhu, i pokud stanovené kritérium neplatí). Co jiného je však ještě naučitelné? Snad pravdivé mínění?

35 Totiž tvrzení, že „co není naučitelné, není věděním“ (srv. Meno, 99a7). 


\section{Interpretace J. Meyersové}

Zajímavé řešení tohoto problému nabízí interpretace Judith Meyersové. ${ }^{36}$ Po geometrické stránce je podobná interpretaci Františka Novotného. Sókratés i v této interpretaci využívá již nakreslený obrazec, jen jej obkrouží kruhem. ${ }^{37}$ Zadaný obdélník ( $\left.\chi \omega @ i ́ o v\right)$, tedy již nakreslený obdélník dva krát čtyři stopy veliký (Meno, 83a), tímto úkonem vepíše

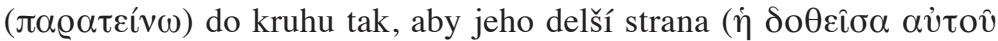

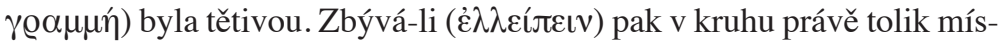
ta, aby dvojnásobný obrazec ležel všemi čtyřmi body na kružnici, je trojúhelník daný podstavou a úhlopř́ičkou onen hledaný.
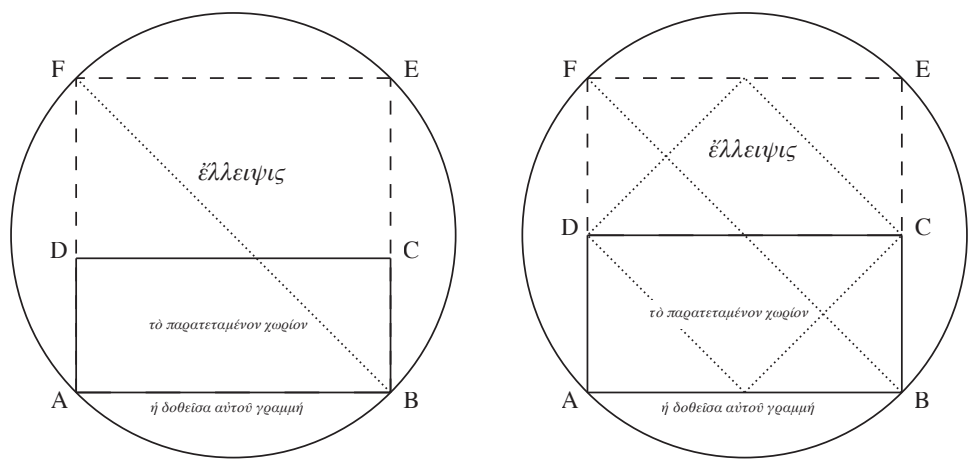

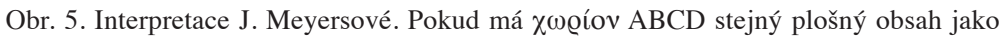
ع้ $\lambda \lambda \varepsilon ı \psi$ ı DCEF, je trojúhelník ABF hledaným vepsáním (nákres vpravo), pokud nikoli, má jinou velikost (nákres vlevo). Na nákresu vpravo je tečkovaně naznačen osmistopý čtverec narýsovaný v dialogu s otrokem. Stojí za povšimnutí, že kdyby ABCD byl čtverec, jde přesně o Královu (Novotného) konstrukci.

Meyersová ovšem chápe celou pasáž odlišně: elegantně se vyhýbá nutnosti vyrovnat se s výše zmíněnými Sókratovými tvrzeními ekvivalence vědění a naučitelnosti tím, že tuto ekvivalenci, stejně jako tvrzení, že zdatnost je dobro, považuje za „filosofické axiomy“. Zkoumanou hypotézou je pak podle ní až tvrzení, že vše, co je dobré, je věděním a vše, co je vědění, je dobré. ${ }^{38}$ Kdyby se totiž podařilo tuto ekvivalenci předvést,

36 J. I. Meyers, Plato's Geometric Hypothesis. Meno 86e-87b, str. 173-180.

$37 \Delta$ เó $\mu \varepsilon \tau \varrho o 5$, dříve zmíněný ve smyslu úhlopříčky (Meno, 85b4-5), tedy využije jako dıó $\mu \varepsilon \tau \varrho o \varsigma$ načrtnutého kruhu. Meyersová v tomto odkazuje na Schultze (F. Schultz, Die zweite mathematische Stelle in Platons Menon).

38 J. I. Meyers, Plato's Geometric Hypothesis. Meno 86e-87b, str. 179. 
s použitím uvedených axiomů by již bylo oprávněné soudit, že zdatnost je naučitelná. Jelikož se však Sókratovi podaří předvést pouze jednu z implikací (totiž že vědění je dobré), postup selhává a není možné učinit žádný úsudek.

Takové čtení je nepochybně výhodné v tom, že na rozdíl od předchozích interpretací se pravdivé mínění přímo nabízí jako protipříklad, kvůli němuž není možné ekvivalenci ustavit. Zároveň však není možné udržet jednoduchou analogii hypotetického důkazu a následného filosofického zkoumání, nebot' na rozdíl od geometrické konstrukce dochází v takto pojatém filosofickém zkoumání $\mathrm{k}$ dvojitému převedení, tj. $\mathrm{k}$ dvojímu užití hypotézy v podobě „filosofického axiomu“.

\section{Interpretace J. Cook Wilsona}

Obecně lze však říct, že moderní interpreti považují chápání hypotetického důkazu jako pouhé implikace za slabinu ${ }^{39}$ všech výše uvedených interpretací a snaží se je bud' opravit, dále specifikovat, ${ }^{40}$ nebo najít jinou interpretaci, takovou, u níž geometrovo kritérium jednoznačně určuje, zda plochu do kruhu vepsat lze, či nikoli.

Patrně nejzajímavější interpretaci opravující interpretaci Butcherovu nacházíme u Cook Wilsona. ${ }^{41}$ Ten konstatuje, že Butcherem zkoumaná

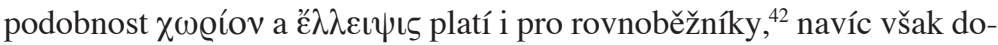
plňuje podstatný vhled: zadanou plochu ( $\chi \omega \varrho i ́ o v)$ můžeme na průměr

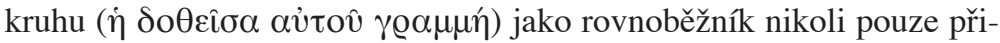
ložit (Butcherovo čtení $\pi \alpha \varrho \alpha \tau \varepsilon i ́ v \omega)$ ), ale libovolně natahovat (takové je Cook Wilsonovo čtení výrazu $\pi \alpha \varrho \alpha \tau \varepsilon i ́ v \omega)$. Jinými slovy, zatímco Butcher nabízí čtení „,pokud je zadaná plocha taková, že...“, Cook Wilson

39 Ale nikoli pouze moderní interpreti. Například Butcher sám podává následující hodnocení: „The solution here proposed has one defect, but not, it would seem, a fatal one... The geometrical hypothesis would no doubt be more satisfactory as a sample of logical method, if the converse proposition also were true. Yet as interpreted above it is sufficient for Socrates' purpose." S. H. Butcher, The Geometrical Problem of the Meno (p. 86e-87a), str. 223.

40 Srv. např. J. Fiala, $\triangle I O P I \Sigma M O \Sigma$ v Platónově Menónovi $(86 e-87 b)$, str. 25.

41 J. Cook Wilson, On the Geometrical Problem in Plato's Meno, 86e sqq., in: The Journal of Philology, 28, 1903, str. 222-240.

42 Nejde o příliš zajímavé zobecnění, nebot' transformace obdélníků na rovnoběžníky daná pouhou změnou úhlu stran žádným způsobem nemění délkové poměry, pouze zmenšuje plošný obsah. Tedy existuje-li vhodný rovnoběžník, tím spíše lze nalézt i vhodný obdélník. 
navrhuje číst: ,„pokud lze zadanou plochu ekvivalentně transformovat na rovnoběžník takový, že...“.43
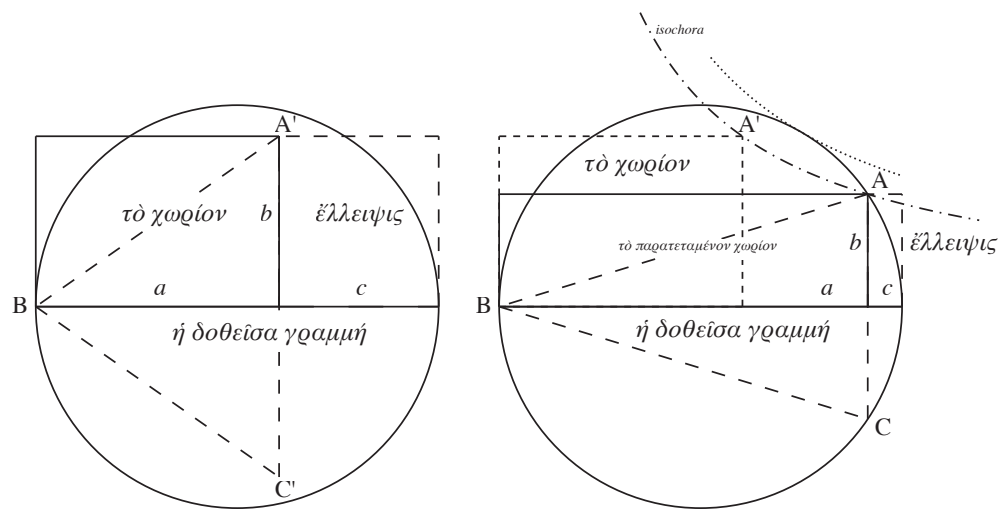

Obr. 6. Cook Wilsonovo řešení. Xw@íov z Butcherova řešení (nákres vlevo) ve skutečnosti vepsat lze, tedy existuje taková jeho ekvivalentní transformace, že podobnost ع̌ $\lambda \lambda \varepsilon ı \psi \iota \varsigma$ a $\chi \omega \varrho i ́ o v$ nastane. Na nákresu vpravo je tato situace naznačena, čerchovaná křivka je „isochora“ (tedy množina všech vrcholů obdélníků se stejným plošným obsahem, přiložených na průměr a majících protilehlý vrchol v bodě B), tam, kde protne kružnici, dostáváme hledanou transformaci. Obecně tedy budou existovat dvě řešení. Tečkovanou křivkou, kdy se „isochora“ kružnice pouze dotýká, je naznačen případ maximálního vepsaného trojúhelníku, tedy trojúhelníku rovnostranného.

Požadovaná transformace bude přitom existovat právě tehdy, pokud lze plochu ve formě trojúhelníku do kruhu vepsat. V analogii hypotetického důkazu jsou tedy vědění a naučitelnost ekvivalentní. Jakkoli je však, jak ukazuje Fiala ${ }^{44}$ sama ekvivalentní transformace rovnoběžníku triviální geometrickou konstrukcí, jež byla Platónovi jistě známá (viz obr. 7), najít tu konkrétní, která by splňovala požadované kritérium podobnosti $\chi \omega \varrho i ́ o v$ a $\varepsilon ̋ \lambda \lambda \varepsilon ı \psi \iota \varsigma$, vyžaduje nalézt průsečík hyperbolické křivky a zadaného kruhu (viz obr. 6).

Jak ale upozorňují všichni kritici této interpretace ${ }^{45}$ pomocí pravítka a kružítka hyperbolu sestrojit nelze. Sókratův geometr tedy nedisponuje

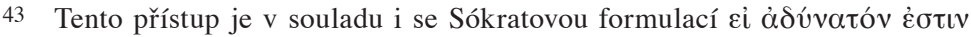

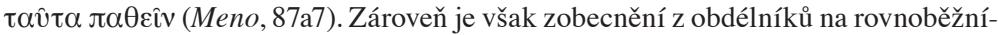
ky zbytečné a věc jen zatemňuje, viz pozn. 42.

44 J. Fiala, $\triangle I O P I \Sigma M O \Sigma$ v Platónově Menónovi (86e-87b), str. 15-16.

45 Viz např. R. S. Bluck, Plato's Meno, str. 448-449, či J. Fiala, $\triangle I O P I \Sigma M O \Sigma$ v Platónově Menónovi (86e-87b), str. 20-21. 
žádnými prostředky, jimiž by mohl konstruktivně ověřit, zda lze konkrétní zadanou plochu do kruhu vepsat. Jestliže má tedy být důkaz $\mathfrak{\varepsilon} \xi$

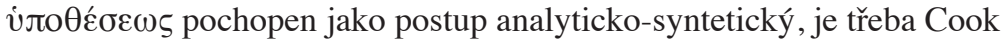
Wilsonovu interpretaci odmítnout.

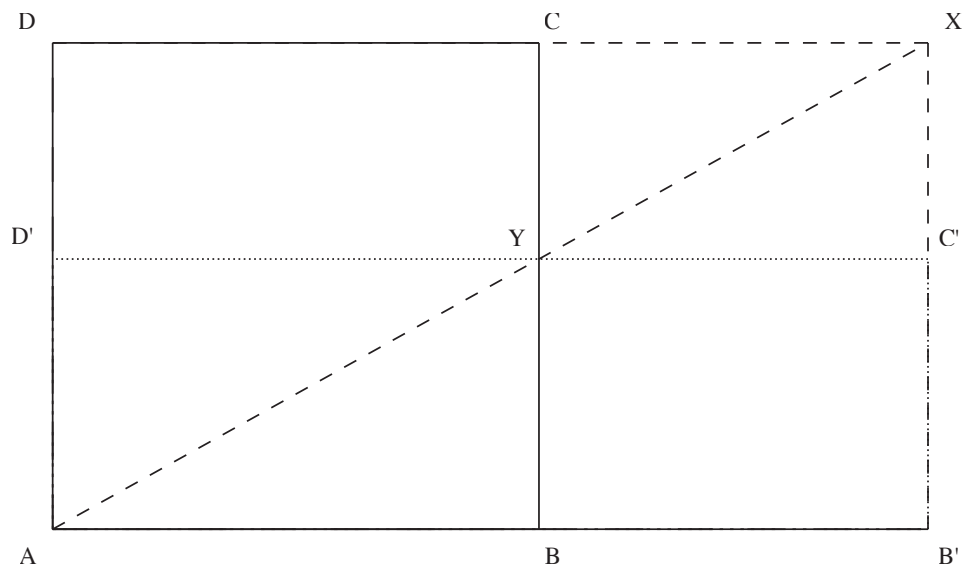

Obr. 7. Ekvivalentní transformace - natažení ( $\pi \varrho \varrho \alpha \tau i ́ v \omega)$ obdélníku ABCD podél úsečky $\mathrm{AB}^{\prime}$, ke které je $\mathrm{ABCD}$ přiložený ( $\left.\pi \alpha \varrho \alpha \beta \alpha \lambda \varepsilon i ̂ v\right)$. V prodloužení strany $\mathrm{DC}$ najdeme průsečík $\mathrm{X}$ s kolmicí na $\mathrm{AB}$ ' vedenou $\mathrm{z}$ bodu $\mathrm{B}$ '. $\mathrm{Z}$ bodu $\mathrm{X}$ vedeme úsečku $\mathrm{AX}$, která má $\mathrm{s}$ úsečkou $\mathrm{BC}$ průsečík $\mathrm{Y}$. $\mathrm{V}$ bodě $\mathrm{Y}$ vedeme rovnoběžku s $\mathrm{AB}$ a v průnicích $\mathrm{s} A \mathrm{AD}$ a $\mathrm{B}^{\prime} \mathrm{X}$ získáváme zbylé body hledané transformace. Důkaz snadno nahlédneme: $\mathrm{AX}$ dělí $\mathrm{AB}$ 'XD, $\mathrm{ABYD}$ ` i YC'XC na poloviny, tedy $B B^{\prime} C^{\prime} Y$ má nutně stejnou plochu jako $D^{`} Y C D$, a i $A B C D$ má tedy stejnou plochu jako $\mathrm{AB} \mathrm{C}^{\prime} \mathrm{C}^{\mathrm{D}}$ ‘, nebot’ $\mathrm{ABYD}$ ‘ je oběma útvarům společná.

Není však bezpodmínečně nutné, aby analýza dospěla až k elementárním konstrukcím, z nichž by byl celek syntetizovatelný. Jak upozorňuje Iwata ${ }^{46}$ již Hippokratés z Chiu při řešení délského problému zdvojení krychle užívá metodu převedení problému na jiný, ačkoli ani původní, ani převedený problém nejsou geometricky řešitelné. ${ }^{47}$

Př́ḱlad Hippokrata z Chiu je o to relevantnější, že možnost konstruktivního ověření Cook Wilsonova kritéria je úzce spjata se schopností zdvojit krychli, ${ }^{48}$ což je problém, který Platóna prokazatelně zají-

\footnotetext{
46 N. Iwata, Plato on Geometrical Hypothesis in the Meno.

47 Tamt., str. 9.

48 R. S. Bluck, Plato's Meno, str. 448. Jak ukázal Menaichmos, zdvojení krychle je možné vyřešit pomocí určení průsečíku dvou kuželoseček, hyperboly a paraboly.
} 
mal. ${ }^{49}$ Je třeba také vzít v úvahu, že v Platónově době nebylo dokázáno, že tento typ problémů pomocí kružítka a pravítka řešit nelze,$^{50}$ tedy převedení problému vepsání plochy na problém nalezení př́íslušné ekvivalentní transformace nelze chápat jako převedení na problém neřešitelný, ale na problém $\mathrm{k}$ řešení potenciálně vedoucí, byt' jeho řešení dosud není známo.

To, že Sókratés staví hypotetický důkaz tak, že převádí problém vepsatelnosti na problém jiný, který ale také neumí řešit, může být nakonec pointou celé pasáže ${ }^{51}$ Menón jej nutí $\mathrm{k}$ jasnému vyjádření, zda je zdatnost naučitelná, ačkoli by bylo třeba spíše zkoumat, čím je (Meno, 86c-d). Sókratés se podvoluje, ale jen v tom smyslu, že počíná zkoumání, zda je zdatnost věděním, a k převedení problému užije geometrickou analogii.

Menón pravděpodobně dokáže nahlédnout, že každou plochu, kterou lze vepsat do kruhu v podobě trojúhelníku, lze vepsat i v podobě trojúhelníku rovnoramenného, a tedy pro ni bude platit Cook Wilsonem navržené kritérium. Naopak to, že Sókratés předvedený analytický krok není schopen rozvinout do plného analyticko-syntetického konstruktivního postupu, Menónovi známo být nemusí. ${ }^{52}$ Sókratés tak jakoby skrytě naznačuje: zkoumejme tedy, zda je zdatnost vědění, avšak tento krok nám nebude nijak nápomocný, nebot' ani toto zkoumání nebudeme schopni dovést ke zdárnému cíli.

V takovéto interpretaci tedy nelze následující pasáže chápat ani jako platný důkaz, že zdatnost věděním je (Meno, 87c-89d), ani jako definitivní vyvrácení toho, že jím není (Meno, 89d-98e). Na skrytou pointu

Cook Wilsonova interpretace také spočívá v nalezení průsečíku dvou kuželoseček, totiž hyperboly a kružnice. Je však pravdou, že kuželosečky poprvé zmiňuje právě Menaichmos, který se narodil patrně až po sepsání dialogu Menón. Pro další diskusi provázanosti obou problémů a datace viz také N. Iwata, Plato on Geometrical Hypothesis in the Meno, str. 8-10.

49 Plútarchos, Quaest. conviv. VIII,2,718e-f.

50 Důkaz nemožnosti zdvojení krychle geometrickými prostř̌edky byl proveden až Pierrem Wantzelem v roce 1837 (L. Wantzel, Recherches sur les moyens de reconnaître si un Problème de Géométrie peut se résoudre avec la règle et le compas, in: Journal de Mathématiques Pures et Appliquées, 2, 1837, str. 366-372).

51 Ostatně kdyby právě tato neřešitelnost nebyla Platónovým záměrem, je nutné Cook Wilsonovu interpretaci zcela odmítnout jako nesmyslnou, protože Platón nepochybně zná metody (například ty zmíněné v interpretacích dále), kterými lze nalézt vepsaný trojúhelník o daném plošném obsahu.

52 Meyersová dokonce s odkazem na fakt, že Menón nebyl školen v geometrii, odmítá všechny složitější interpretace (J. I. Meyers, Plato's Geometric Hypothesis, Meno $86 e-87 b$, str. 175 a pozn. 9). 
hypotetického důkazu by pak navazoval až sám závěr dialogu (Meno, $100 \mathrm{a}-\mathrm{c})$, v němž Sókratés předchozí vyjádření oslabuje a dialog uzavírá s tím, že člověk, jehož zdatnost by byla naučitelná (a tedy založená ve vědění), by byl co do této zdatnosti ,jako skutečná věc vedle stínů“ (Meno, 100a). ${ }^{53}$ To, zda je ovšem takový případ reálně možný, nechává otevřené s tím, že odpověd závisí na zodpovězení otázky, čím zdatnost je: právě tato otevřenost odpovídá neschopnosti ověřit kritérium hypotetického důkazu.

\section{Interpretace A. Farqaharsona}

Jakkoli je Cook Wilsonova interpretace stále diskutována, většina moderních interpretů se snaží v textu pasáže hypotetického důkazu nalézt takovou konstrukci, která by jednoznačně stanovila, zda plochu lze, či nelze vepsat, a která by zároveň obsahovala celý analyticko-syntetický postup, tedy umožňovala by vepsaný trojúhelník o daném plošném obsahu přímo zkonstruovat.

Patrně nejstarší takovou interpretací je interpretace Farqaharsonova. ${ }^{54}$ Ten si všímá toho, že pokud lze plochu do kruhu jako trojúhelník vepsat, kterákoli z jeho těžnic (tedy úsečka vedená z vrcholu ke středu protilehlé strany) jej dělí na dvě poloviny se stejným plošným obsahem, ${ }^{55}$ a tedy rovnoběžník, jehož jednou stranou je zmíněná těžnice a druhou polovina strany, na kterou je těžnice vedena, má plošný obsah shodný s plošným obsahem celého vepsaného trojúhelníku. Zároveň jeho úhlopříčka je také tětivou kruhu a jeho doplnění ("̌̉ $\lambda \lambda \varepsilon ı \psi ı \varsigma)$ do rovnoběžníku daného stranou, na kterou byla vedena těžnice, a touto těžnicí je přesně plošně totož-

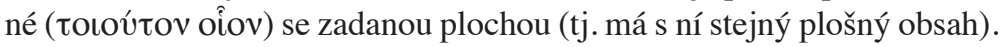

Pokud by se tedy podařilo nalézt takovou tětivu kruhu ${ }^{56}$

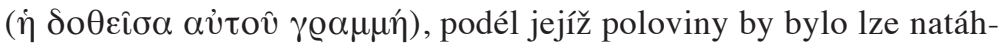
nout ( $\pi \alpha \varrho \alpha \tau \varepsilon i ́ v \omega)$ zadanou plochu ( $\chi \omega \varrho i ́ v v)$ jako rovnoběžník tak,

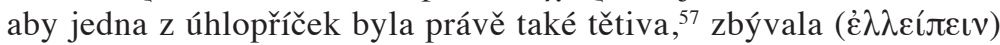

53 Citováno dle překladu F. Novotného.

54 A. S. L. Farqaharson, Socrates' Diagram in the Meno of Plato. Pp. 86e-87a, in: The Classical Quarterly, 1, 17, 1923, str. 21-26.

55 Důkaz je zřejmý: těžnice dělí trojúhelník na dva, oba o stejné výšce a shodně dlouhé základně.

$56, \ldots$ the problem is solved by finding a chord of the circle such that a parallelogram equal to the given figure..." A. S. L. Farqaharson, Socrates' Diagram in the Meno of Plato, str. 23.

57 Tento požadavek však není zřejmý a Sókratés jej nikde nezmiňuje. Farqaharson o tomto problému hovoří: „Plato tacitly assumes that a parallelogram construc- 


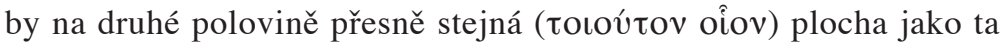
již daná.

Farqaharsonovu interpretaci je však třeba poopravit, nebot' $\mathrm{z}$ autorových formulací není jasné, jak hledanou tětivu a transformaci plochy konstruktivně nalézt. ${ }^{58}$ Návod k opravě ovšem dává již sám Farqaharson, když ve svém náčrtku za hledanou tětivu považuje stranu do kruhu vepsaného rovnostranného trojúhelníku. V článku pak sám navrhuje jednoduchou konstrukci (viz obr. 8), která s touto volbou počítá. ${ }^{59}$
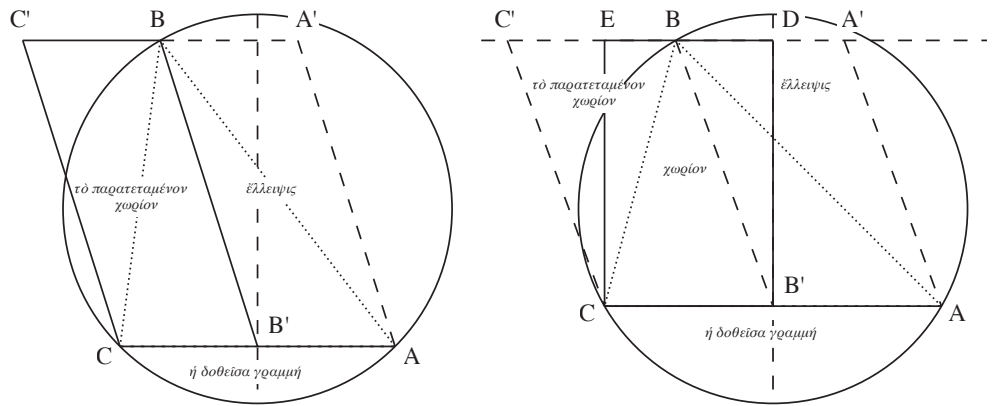

Obr. 8. Farqaharsonovo řešení. Pokud na nákresu vlevo nalezneme takovou tětivu CA, že nad její polovinou $\mathrm{CB}$ ‘ dokážeme vztyčit rovnoběžník o obsahu zadaného $\chi \omega \varrho i ́ o v$

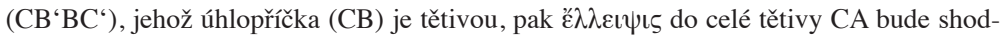
ná s tímto $\chi \omega \varrho i ́ o v$ a trojúhelník $\mathrm{ABC}$ bude hledané vepsání. Pokud tětiva $\mathrm{CA}$ a zároveň

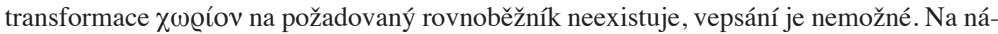
kresu vpravo je znázorněna oprava umožňující príimé zkonstruování trojúhelníku: za tětivu CA vezmeme základnu rovnostranného trojúhelníku. Na její polovinu vztyčíme zadané $\chi \omega \varrho i ́ o v(\mathrm{CB} ` \mathrm{DE})$ ve formě obdélníku. Farqaharsonem hledaná úhlopříčka transformovaného $\chi \omega \varrho i ́ o v$ je pak dána bodem $\mathrm{C}$ a průsečíkem přímky $\mathrm{DE}$ se zadanou kružnicí (B). Pokud průsečík nevznikne, plochu vepsat ve formě trojúhelníku nelze. Pokud ano, trojúhelníku ABC je hledané vepsání.

ted with a reference to a circle is described on (or along) a chord, and has one of its diagonals likewise a chord.“ Tamt., str. 24. Avšak nesprávně má za to, že všechny předcházející interpretace s tímto požadavkem počítají také, přičemž zmiňuje pouze Beneckeho a Augusta (E. F. August, Zur Kenntniss der geometrischen Methode der Alten in besonderer Beziehung auf die Platonische Stelle im Meno, Berlin 1843). Kupříkladu Cook Wilson tento požadavek neklade: v jeho čtení pro obdélníky vyplývá z povahy věci, pro obecné rovnoběžníky nikoli.

58 To kritizuje např́íklad Bluck (viz S. Bluck, Plato's Meno, str. 458).

59 A. S. Farqaharson, Socrates' Diagram in the Meno of Plato, str. 24. 


\section{Interpretace A. Heijboera, R. Sternfelda a H. Zyskinda}

Zcela jiný postup navrhují Sternfeld a Zyskind, ${ }^{60}$ kteří opravují starší interpretaci Heijboerovu. ${ }^{61}$ Heijboer odmítá technický význam

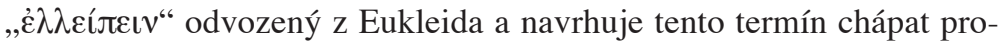
stě jako „zbývá místo“. Zadaný obdélník ${ }^{62}$ ( $\left.\chi \omega \varrho i ́ o v\right)$ je tedy podle něj

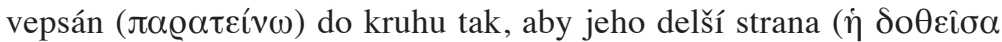

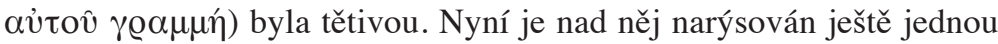

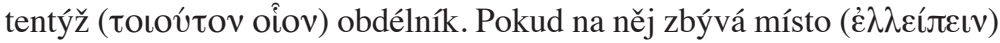
v tom smyslu, že celková výška takto zdvojeného obrazce nebude větší než vzdálenost kruhu od výše uvedené tětivy, lze horní úsečku útvaru protáhnout tak, že bude mít alespoň jeden průsečík se zadanou kružnicí. Pokud je pak tento průsečík uchopen jako třetí bod k dvěma bodům již nakreslené tětivy, výsledkem je hledaný vepsaný trojúhelník.

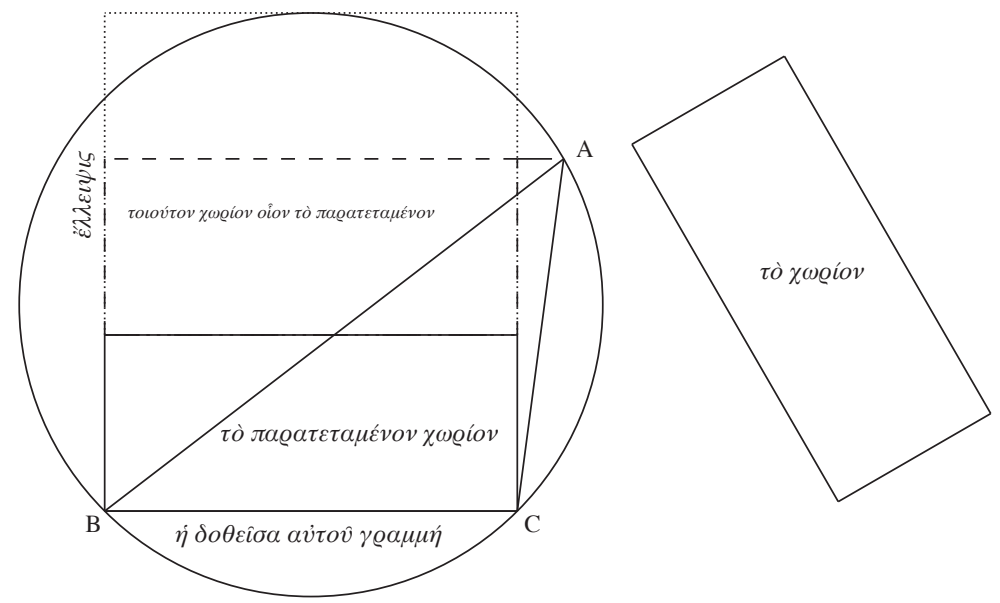

Obr. 9. Heijboerovo řešení a řešení Sternfelda a Zyskinda. Zadané obdélníkové $\chi \omega$ wíov vepíšeme do kruhu ( $\pi \alpha \varrho \alpha \tau \varepsilon i ́ v \omega)$ tak, aby delší strana byla tětivou (BC). Pokud nad tímto

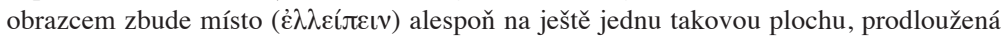
horní strana protne kruh (v bodě A) a trojúhelník ABC bude hledaným vepsáním. Sternfeldovo a Zyskindovo řešení se principiálně neliší, pouze plocha se nejdříve transformuje tak, aby jedna ze stran byla stranou do kruhu vepsaného rovnostranného trojúhelníku. Tuto stranu pak autoři považují za tětivu zmíněnou v první větě.

\footnotetext{
60 R. Sternfeld - H. Zyskind, Plato's Meno: $86 E-87 A$.

61 A. Heijboer, Plato. Meno $86 e-87 a$.

62 Je vhodné poznamenat, že celý argument funguje i pro rovnoběžníky. Totéž pak platí i pro Sternfeldovu a Zyskindovu interpretaci.
} 


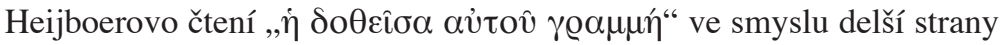
zadané obdélníkové plochy je jazykově elegantní, avšak způsobuje, že některé plochy nebude možné tímto způsobem do kruhu vepsat, ačkoli obecně je vepsat jako trojúhelník lze (například čtverec o straně shodné s poloměrem kruhu, srv. obr. 3, nákres vpravo). Sternfeld a Zyskind pro-

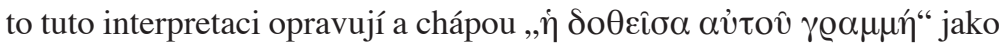
základnu vepsaného rovnostranného trojúhelníku a „, $\alpha \varrho \alpha \tau \varepsilon i ́ v \omega “$ jako

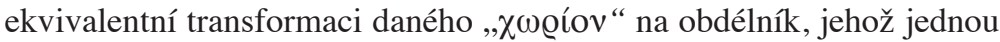

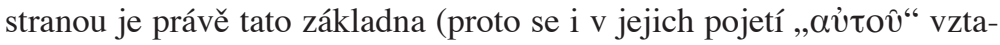

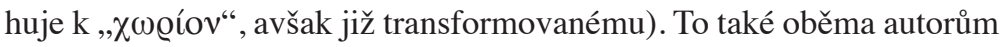

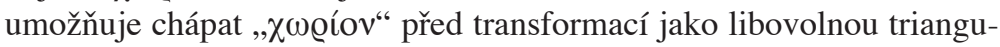
lovatelnou plochu.

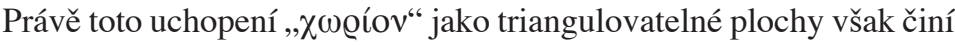
celou konstrukci zbytečně složitou, při její transformaci na obdélník se stranou rovnou základně rovnostranného trojúhelníku je navíc Sternfeldem a Zyskindem užit absurdně těžkopádný geometrický aparát. To vede např́klad Meyersovou k odmítnutí celé interpretace, nebot' se domnívá, že takto složitá konstrukce by byla pro Menóna nepochopitelná. ${ }^{63}$ Interpretaci je však možné Menónovi přiblížit, jednak návratem k předpokladu, že zadanou plochou je obdélník či čtverec, jednak užitím aparátu pro ekvivalentní transformace uvedeného na obr. $7 .^{64}$

Schopnost konstruktivně ověrit, zda danou plochu lze do kruhu ve formě trojúhelníku vepsat, či nikoli, a v případě, že lze, přímo nalézt hledané vepsání, je nepochybně v plném souladu se stávajícím pochopením řecké geometrie. Otázkou je, zda opět netvoří př́lišné obtíže při celkové interpretaci dialogu. Zdá se totiž, že tento typ interpretace nelze chápat jako analogii dalšího postupu Sókratova filosofického zkoumání, ale výhradně jako popis metody $\dot{\varepsilon} \xi \dot{v} \pi 0 \theta \dot{\varepsilon} \sigma \varepsilon \omega \varsigma$.

Pokud by totiž byl hypotetický důkaz chápán analogicky následujícímu textu dialogu, bylo by potřeba, aby Sókratovo zkoumání dospělo $\mathrm{k}$ jasnému výsledku, at' už v tom smyslu, že zdatnost věděním je, nebo v tom, že není. K takovému výsledku však dialog nedospěje. Hypotetickou metodu sice lze vztáhnout pouze na bezprostředně následující pasáž (Meno, 87c-89c) a chápat důkaz toho, že zdatnost je věděním, jako platný, pak je ale nutné se vyrovnat s jeho následným zpochybněním.

63 J. I. Meyers, Plato's Geometric Hypothesis. Meno 86e-87b, str. 173.

64 Tuto interpretaci nabízí také Fiala, viz J. Fiala, $\triangle I O P I \Sigma M O \Sigma$ v Platónově Menónovi (86e-87b), str. 18-19. 
Avšak snad by bylo možné obdobně jako u Cook Wilsonovy interpretace chápat zdatnost předních athénských mužů založenou na pravdivém mínění pouze za jakýsi stín pravé zdatnosti, která je vskutku věděním. Pak by také bylo zřejmé, proč je těžké či nemožné najít učitele zdatnosti: naučitelné je pouze vědění a tito mužové zdatnost jakožto vědění nemají. Homérovskou citací na samém konci dialogu (Meno, 100a), jež nápadně upomíná na obraz jeskyně z Ústavy (Resp. 514a-518b), by tak mohl Platón naznačovat, kde právě takové učitele zdatnosti hledat: jsou jimi filosofové a především sám Sókratés.

Jak už však bylo uvedeno, pro platnost důkazu je zároveň třeba, aby jediné, co je prospěšné, bylo vědění. Tím ale narážíme na obtíž, nebot' přece „správné mínění není o nic méně prospěšné nežli vědění“ (Meno, 97c). Sotva lze totiž tvrdit, že i prospěšnost se vypovídá dvojím způsobem, totiž jako pravá prospěšnost a její pouhý stín.

Jakkoli tedy Platónovou pointou skutečně může být výše uvedená diferenciace zdatnosti, co se týče pasáže hypotetického důkazu, lépe jí odpovídají Cook Wilsonova interpretace či interpretace J. I. Meyersové.

\section{Závěrem}

Ačkoli se jednotlivé interpretace liší navrhovanými geometrickými konstrukcemi, lze konstatovat, že všechny spadají do některé ze tří základních skupin. První skupina je ta, podle níž geometr dokáže svou konstrukcí ověřit, že danou plochu lze do kruhu vepsat v podobě trojúhelníku. Pokud však dané kritérium selže, neplyne z toho, že plochu nelze vepsat. Druhá skupina interpretací - kterou tvoří pouze interpretace Cook Wilsonova - sice předpokládá, že geometrovo kritérium dokáže jednoznačně rozlišit, zda je plocha vepsatelná, či není, ale splnění tohoto kritéria není možné konstruktivně ověřit. Nakonec třetí skupina interpretací stanovuje kritérium tak, že jednoznačně rozhoduje o vepsatelnosti plochy a navíc, pokud je toto vepsání možné, geometr plochu svou konstrukcí přímo vepíše. Přesněji řečeno, geometr, resp. Sókratés, přirozeně nemusí analyticko-syntetický postup plně uskutečnit, nicméně má možnost tak učinit.

Podle interpretace nabízené první skupinou pak struktura hypotetického důkazu - z hlediska filosofického chápání dialogu - naznačuje, že ačkoli se zdatnost neukázala být věděním, může ještě stále být naučitelná. Výjimku tvoří interpretace J. I. Meyersové, podle níž celý důkazní postup selhává na neschopnosti ukázat ekvivalenci dobra a vědění, 
a tedy nelze ani rozhodnout, zda je zdatnost naučitelná, ani to, zda je, či není věděním. Cook Wilsonovo čtení naproti tomu potvrzuje, že jediné, co je možno učit, je vědění, avšak určit, zda je zdatnost věděním, Sókratés nedokáže, přičemž hypotetickým důkazem tuto svou neschopnost předem naznačuje. V interpretacích ze třetí skupiny pak hypotetický důkaz patrně slouží pouze jako představení metody a ke zbytku dialogu se vztahuje pouze v tomto smyslu.

Je možné, aby existovaly ještě jiné, strukturně odlišné možnosti, jak pasáž hypotetického důkazu interpretovat? V principu ano, obě

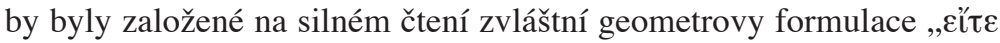

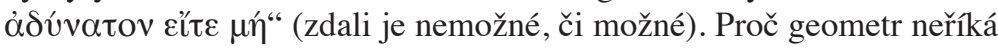

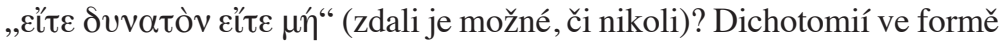

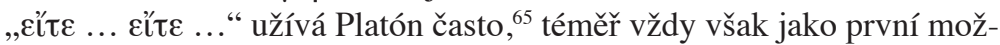
nost uvádí možnost pozitivní. ${ }^{66}$

Jednou z dalších možností, jak pasáž hypotetického důkazu číst, je tedy ta, že geometrova konstrukce neověřuje možnost vepsání do kruhu, ale naopak její nemožnost. U interpretací, v nichž kritérium jednoznačně rozhoduje, zda plochu vepsat lze, či nikoli, tato změna čtení nic nepřináší. Bylo by však možné myslet kritérium, které by dokázalo ověřit, zda plochu do kruhu vepsat nelze, pokud by však toto kritérium selhalo, mohlo by být stále nemožné tuto plochu vepsat?

Takové kritérium by snad existovat mohlo, ale najít postup, který by byl věrný textu a zároveň by zjevně dokazoval nemožnost vepsání, není snadné. $\mathrm{K}$ interpretaci dialogu však tato možnost nic nepřidává nebot' je v principu totožná s interpretacemi skupiny první -, naopak ji znesnadňuje. V dalším textu totiž analogickou negativní strukturu nenacházíme. ${ }^{67}$

Nadějnější možností, která má navíc skutečně odlišný dopad na čtení dialogu, je interpretace, že Sókratův hypotetický důkaz je záměrně chybný. Lze si představit, že Sókratés přátelsky zneužívá Menónovy nezběhlosti v geometrii, kreslí do písku kritérium odpovídající některé

65 Srv. Platón, Meno, 90b9, 87b4, 86d4-5, 71a5-6, a mnohá jiná místa, např. Platón, Resp. 435c5-6, Polit. 304b5, Phd. $70 b 7$ ad.

66 Jednou z mála dalších takto negativně formulovaných dichotomií je Anytova promluva z konce dialogu (Meno, 92c5), kde však Anytos přímo odpovídá na Só-

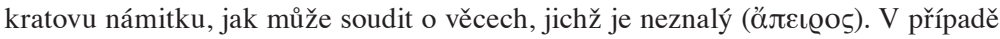
hypotetického důkazu však k negativní formulaci žádný zjevný důvod neexistuje.

67 Implikaci „čeho neexistují učitelé, to není naučitelné“ (Meno, 89e) nelze počítat, protože na rozdíl od takto uchopeného hypotetického důkazu má negaci i v antecedentu. 
z interpretací z první skupiny - např́íklad Beneckeho konstrukci -, avšak stanovuje závěr nesprávně jako opačnou implikaci: pokud zbytek do prů-

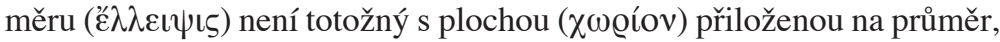
plochu ve formě trojúhelníku do kruhu vepsat nelze.

Takováto interpretace by znamenala, že Sókratés již v pasáži hypotetického důkazu předjímá neplatnost následujícího vyvození, že zdatnost je věděním. A skutečně, chyba v tomto vyvození se zdá mít právě charakter obrácení implikace. ${ }^{68}$

Zároveň by však v takovém případě nebylo možné pasáž chápat jako platné představení metody ’̇ $\xi$ vं jmout jen s obtížemi. Dialog Menón je totiž třeba číst nejen jako zkoumání toho, co je to zdatnost, ale také jako zkoumání možností zkoumání jako takového. Chybné představení hypotetické metody jakožto důležitého způsobu teoretického zkoumání by tedy - jakkoli by mohlo být v rámci narativu oprávněné - čtenářům dialogu nečinilo dobrou službu.

Spolu s dvěma výše uvedenými interpretacemi jsou však již vyčerpány základní strukturální možnosti toho, jak pasáž hypotetického důkazu číst. ${ }^{69}$ Všechny mají své slabiny, at' už z hlediska současného chápání antické matematiky, či z hlediska celkového čtení dialogu. Lze se tedy $\mathrm{k}$ některé $\mathrm{z}$ nich přiklonit?

Jako filosoficky nejzajímavější se jeví Cook Wilsonova geometrická konstrukce. Pokud totiž rozlišíme učení, kterým se získává vědění tj. vzpomínání -, a „učení“, kterým se získává správné mínění - například pokud jde o to, zapamatovat si cestu do Larisy (Meno, 97a-b) -, zdá se být udržitelné, že to jediné, co je naučitelné v pravém slova smyslu, je vskutku vědění. Zároveň je zřejmé, že Sókratovi se v rámci dialogu nedaří dokázat ani vyvrátit, že zdatnost je věděním. Identifikuje sice určitou zdatnost, která je založena ve správném mínění, ta je však - podobně jako správné mínění ve vztahu k vědění - pouze stínem zdatnosti v pravém slova smyslu.

Je tato zdatnost v pravém slova smyslu ale věděním? Vypomoci si můžeme definicí z Ústavy, podle níž je zdatnost ,,jaksi zdraví a krása a dobrý stav duše, kdežto špatnost je nemoc a ohyzdnost a slabost"“ a podle

68 Tato chyba spočívá v úsudku, že pokud je zdatnost prospěšná a pokud je rozumnost prospěšná, pak je rozumnost zdatností nebo nějakou její částí (Meno, 89a). Aby toto vyvození bylo správné, muselo by navíc platit, že cokoli je prospěšné, je zdatností (což není pravda), nebo to, že cokoli je prospěšné, je rozumností (v tomto případě lze jako protipř́íklad uvést správné mínění).

69 Nelze samozřejmě vyloučit, že bude nalezena nová geometrická konstrukce odpovídající textu pasáže. Z hlediska logické struktury však bude nutně spadat do jedné z představených skupin. 


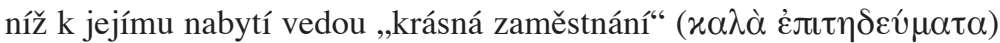
(Resp.444d13-e6). Zdá se tedy, že pojem zdatnosti v sobě nese i habituální aspekt, který není zcela přímočaře identifikovatelný s věděním. $\mathrm{Na}$ jedné straně lze říci, že opakovaná vzpomínka, tj. učení v pravém slova smyslu, na některé skutečnosti - např. na krásu - má i eticky formativní sílu (srv. Phaedr. 254b-e). Na druhé straně se však nezdá, že by vědění obecně vynucovalo zdatnost (srv. Hipp. Mi. 375e9-376a1). Ačkoli tedy lze souhlasit s tím, že to, co je na věcech duše dobré, je rozumnost (Meno, 88e-89a), není zřejmé, zda samotné vědění je postačující podmínkou zdatnosti.

V Cook Wilsonově čtení tedy Sókratés předjímá tyto obtíže již v pasáži hypotetického důkazu. Geometrova konstrukce je elegantní, ale naráží na hluboký problém, o němž Platón dopředu ví, že jej nedokáže uspokojivě vyřešit. Pravá zdatnost je nepochybně založena ve vědění, ale zda je přímo věděním (například dobra), či ještě něčím jiným, co nelze učit, zůstává otevřeno.

\section{Dodatek: varianty českého překladu}

Pro českého čtenáře by mohlo být zajímavé, jaké odlišnosti v překladu příslušné pasáže vyplývají z pojetí jednotlivých interpretů. Uvádíme zde tedy modifikace Novotného překladu tak, aby odpovídaly jejich konstrukcím. Modifikace jsou vyznačeny kurzivou.

\section{A. Benecke}

„Ještě to nevím, zdali je tato plocha taková, ale myslím, že mám jistý vhodný předpoklad pro tuto věc, a to takový: jestliže je tato plocha taková, že její doplněk [do prưměru] je stejný, jako ona sama, zdá se mi, že vychází něco, a zase něco jiného, jestliže není možné, aby se to s ní stalo. S užitím předpokladu tedy ti chci říct, co vychází o jejím vepsání do kruhu, zdali je nemožné, či možné.“

\section{S. H. Butcher}

„Ještě to nevím, zdali je tato plocha taková, ale myslím, že mám jistý vhodný předpoklad pro tuto věc, a to takový: jestliže je tato plocha taková, že když ji přistavím na průměr, bude její doplněk [do průměru] podobný jí samé, zdá se mi, že vychází něco, a zase něco jiného, jestliže není možné, aby se to s ní stalo. S užitím předpokladu tedy ti chci říct, co vychází o jejím vepsání do kruhu, zdali je nemožné, či možné.“ 


\section{J. Meyersová, 7. A. Heijboer}

„Ještě to nevím, zdali je tato plocha taková, ale myslím, že mám jistý vhodný předpoklad pro tuto věc, a to takový: jestliže je tato plocha taková, že kdyžji její stranou přiložím [na kruh], zbude [nad ní] místo právě na týž obrazec, zdá se mi, že vychází něco, a zase něco jiného, jestliže není možné, aby se to s ní stalo. S užitím předpokladu tedy ti chci říct, co vychází o jejím vepsání do kruhu, zdali je nemožné, či možné.“

\section{J. Cook Wilson}

„Ještě to nevím, zdali je tato plocha taková, ale myslím, že mám jistý vhodný předpoklad pro tuto věc, a to takový: jestliže je tato plocha taková, že ji mohu [jako rovnoběžník] natáhnout na prüměr tak, že jeji doplněk [do průměru] bude podobný jí samé, zdá se mi, že vychází něco, a zase něco jiného, jestliže není možné, aby se to s ní stalo. S užitím předpokladu tedy ti chci říct, co vychází o jejím vepsání do kruhu, zdali je nemožné, či možné.“

\section{A. Farqaharson}

„Ještě to nevím, zdali je tato plocha taková, ale myslím, že mám jistý vhodný předpoklad pro tuto věc, a to takový: jestliže je tato plocha taková, že ji mohu jako rovnoběžník [jehož úhlopřička je tětivou] postavit na danou úsečku [odpovídající základně vepsaného rovnostranného trojúhelníka] tak, že jeho doplněk bude rovný jemu samému, zdá se mi, že vychází něco, a zase něco jiného, jestliže není možné, aby se to s ní stalo. S užitím předpokladu tedy ti chci říct, co vychází o jejím vepsání do kruhu, zdali je nemožné, či možné.“

\section{R. Sternfeld a H. Zyskind}

„Ještě to nevím, zdali je tato plocha taková, ale myslím, že mám jistý vhodný předpoklad pro tuto věc, a to takový: jestliže je tato plocha taková, že kdyžji [jako obdélník] natáhnu na danou úsečku [odpovídajicí základně vepsaného rovnostranného trojúhelníka], zbude [nad ní] místo na týž obrazec, zdá se mi, že vychází něco, a zase něco jiného, jestliže není možné, aby se to s ní stalo. S užitím předpokladu tedy ti chci říct, co vychází o jejím vepsání do kruhu, zdali je nemožné, či možné.“ 


\section{ZUSAMMENFASSUNG}

Dieser Beitrag richtet seine Aufmerksamkeit auf den zweiten geometrischen Beweis in Platons Menon (86e4-87b2). Beabsichtigt wird eine Darstellung von neueren Interpretationen des besagten Abschnittes und eine Untersuchung von ihren Auswirkungen auf das philosophische Verständnis des Dialogs im Ganzen. Aus diesem Grund konzentriert sich der Beitrag hauptsächlich auf die logische Struktur von drei Interpretationsgruppen. Diese Interpretationen beruhen (1) entweder auf dem Verständnis des Abschnitts als einer Implikation, bzw. als einer Äquivalenz zwischen dem geometrischen Kriterium und der Existenz einer Lösung des Problems. Oder (2) sie stützen sich auf die Fähigkeit des Geometers, das Kriterium prüfen zu können. Im Beitrag werden auch andere logische Möglichkeiten diskutiert und zugleich wird zugunsten von Cook Wilsons Interpretation des Abschnittes argumentiert.

\section{SUMMARY}

The paper focuses on the second geometrical proof in Plato's Meno (86e4-87b2). Its purpose is to present the modern interpretations of the passage and to explore their implications for the philosophical reading of the dialogue as a whole. Therefore, it focuses mainly on the logical structure of three groups of interpretations. The interpretations are based on (1) whether they understand the passage as an implication or rather an equivalence between the geometric criterion and the existence of the solution of the problem, and (2) whether they imply the geometer's ability to check the criterion. The paper also discusses other logical possibilities and argues for Cook Wilson's interpretation of the passage. 